[Bull. Agr. Chem. Soc. Japan, Vol. 20, No. 4, p. 211 214, 1956]

\title{
Phytopathological Chemistry of Black Rot Sweet Potato
}

\section{Part XXVI. Activity of Proteolytic Enzymes in the Diseased Sweet Potato}

\author{
By Hitoshi ShIChI and Ikuzo URITANI \\ Laboratory of Biochemistry, Faculty of Agriculture, Nagoya University
}

Received June 27, 1956

\begin{abstract}
The proteolytic enzyme system in the tissues of sweet potato root was partially purified and its several characteristics were investigated. Based on the results from these preliminary experiments, we found that proteolytic activity in the tissues suffering from black rot declines as penetration of the pathogen proceeds. Procedures to extract the enzyme system from the affected plant tissues were also established. The diminution in activity of the affected tissues was discussed in connection with those results reported hitherto.
\end{abstract}

It has previously been shown that an increase in the respiratory-rate is observed in the healthy part next to the affected site when sweet potato is infected with Ceratostomella fimbriata. ${ }^{1)}$ This respiratory increase is accompanied with the reduction of the inorganic phosphate level and concomitant increase of organic phosphates in that same part.2) Together with the results obtained from the experiment in which the effects of 2,4dinitrophenol and other uncoupling substances have been tested on the respiratory increase, ${ }^{3)}$ we have postulated that a considerable portion of this respiratory increase may be closely connected with the oxidative phosphorylation. In line with these experiments, the ratio of acid insoluble to acid soluble-nitrogen in the part mentioned above has been investigated resulting that the ratio gradually increases as infection proceeds, while the total nitrogen level of the mentioned part remains constant.

These results have led us to the conclusion that sweet potato tissues may respond to disease development with new protein syn-

1) I. Uritani and S. Takita, J. Agr. Chem. Sac. Japan, 27, 168 (1953).

2) T. Akazawa and I. Uritani, ibid, 29, 381 (1955).

T. Akazawa and I. Uritani, Nature, 176, 1071 (1955).

3) I. Uritani, T. Akazawa and M. Uritani, ibid, 124, 1060 (1954). thesis and perhaps accompany rearrangement of the reserved proteins. By all mean, these active processes call for energy supply from, for example, ATP, and this requisition, in turn, stimulates the increase of the ADP level, which is a limiting principle of the respiratory-rate.3,4,5,6) This causes an increase in the oxygen uptake in the long run. Some evidences are at present available which seem to support this picture; in black rot sweet potato, oxidizing enzymes such as polyphenol oxidase, cytochrome oxidase and peroxidase are activated to a considerable degree.7) Furthermore, it has recently been found that in the sound part adjacent to the infected, protein fractions electrophoretically differ from those prepared from the healthy tissues, and the nitrogen amount of the cytoplasmic particulates, such as mitochondria increases. $\left.{ }^{8}\right)$ Thus, functional proteins either synthesized or reorganized, appear to be of particular importance to comprehend the biochemical mechanism of the host-parasite interaction.

In the present investigation, the alteration of

4) F. Lynen, Ann., 546, 120 (1941).

5) M.J. Johnson, Science, 94, 200 (1941).

6) P. Siekevicz and V. Potter, J. Biol. Chem., 20x, 1 (1953).

7) I. Uritani and T. Akazawa, J. Agrr. Chem. Soc. Japan, 27, 789 (1953)

8) T. Akazawa, J. Biochem., in press. 
activity of proteolytic enzymes which may take part in the protein metabolism of black rot sweet potato has therefore been studied. Investigations concerning the endoproteases of higher plants have scarcely been done, except for a few plants. Studies dealing with the change of proteolytic activities in higher plants in terms of disease resistance are also meager. Preliminary experiments have, therefore, been undertaken to examine several characteristics of this enzyme system so that they will serve for our end to investigate the changes of proteolytic activity in the sweet potato tissues suffering from black rot.

\section{METHODS}

Fresh sweet potato tissues (Norin No. 2 var.) were pealed, chopped and homogenized with a three fold volume of $0.04 \mathrm{M}$ phosphate buffer, centrifuged at $170 \times \mathrm{g}, 10 \mathrm{~min}$. For the estimation of the effect of $\mathrm{pH}$ upon proteolytic activity, a supernatant solution as follows was employed. A couple of reaction mixtures containing enzyme solution, buffer of a definite $\mathrm{pH}$ and 5\% casein, in equal volume were prepared. One of them was deproteinized with an equal volume of $0.6 \mathrm{M}$ trichloroacetic acid (TCA) at zero time. The other reaction mixture incubated at $30^{\circ} \mathrm{C}$, was shaken with TCA in the same manner after a $4 \mathrm{hr}$. incubation. Activity was followed both colorimetrically and spectro-photometrically. The effect of some activators and inhibitors and also that of temperature were investigated as follows: To the supernatant solution, $\left(\mathrm{NH}_{4}\right)_{2} \mathrm{SO}_{4}$ was added up to 0.6 saturation, the solution centrifuged at $7000 \times \mathrm{g}, 10 \mathrm{~min}$., then the resultant precipitate resuspended in a minimal volume of phosphate buffer of $\mathrm{pH}$ 7.0. This partially purified preparation was used as the enzyme solution. Reaction mixtures containing $3 \mathrm{ml}$ of enzyme solution, $2 \mathrm{ml}$ of $5 \%$ casein, $2 \mathrm{ml}$ of buffer and $2 \mathrm{ml}$ of $0.002 \mathrm{M}$ activator or inhibitor were prepared, and incubated for $2 \mathrm{hrs}$. at $30^{\circ} \mathrm{C}$. Before and after incubation the reaction mixtures were shaken with $11 \mathrm{ml}$ of $30 \%$ TCA.

The effect of temperature was tested with neither activators nor inhibitors. The activity determination was carried out spectrophotometrically.

In the colorimetric method, to $1 \mathrm{ml}$ of the TCA filtrate, $5 \mathrm{ml}$ of $0.4 \mathrm{M} \mathrm{Na} \mathrm{NaO}_{3}$ and $1 \mathrm{ml}$ of Folin reagent were added. After allowing to stand at room temperature for $20 \mathrm{~min}$., the colour development was determined. In the spectrophotometric method, $4 \mathrm{ml}$ aliquots of each filtrate were diluted to $10 \mathrm{ml}$ with distilled water, and their absorption at $280 \mathrm{~m} \mu$ was determined with a Shimazu quarts-spectrophotometer. Proteolytic activity was expressed as the optical density increment of the incubated solution minus those of the corresponding blanks incubated without either the substrate or the enzyme.

In dealing with black rot sweet potato, attention must be paid to the fact that a considerable amount of polyphenolic compounds accumulate in healthy part next to the infected, and when exposed to air on homogenation of the sample, these compounds are subjected to rapid oxidation to quinones which react with amino acids and perhaps also with proteins, thus consequently resulting in the accumulation of melanin compounds 9 . These groups of compounds produced might more or less exert influence upon the proteolytic enzyme activity itself and the measurements of activity by the $280 \mathrm{~m} \mu$ absorption. The

\section{TABLE I}

Procedures of the Acetone Powder PreparaTIONS AND OF THE EXTRACTION OF ENZYME

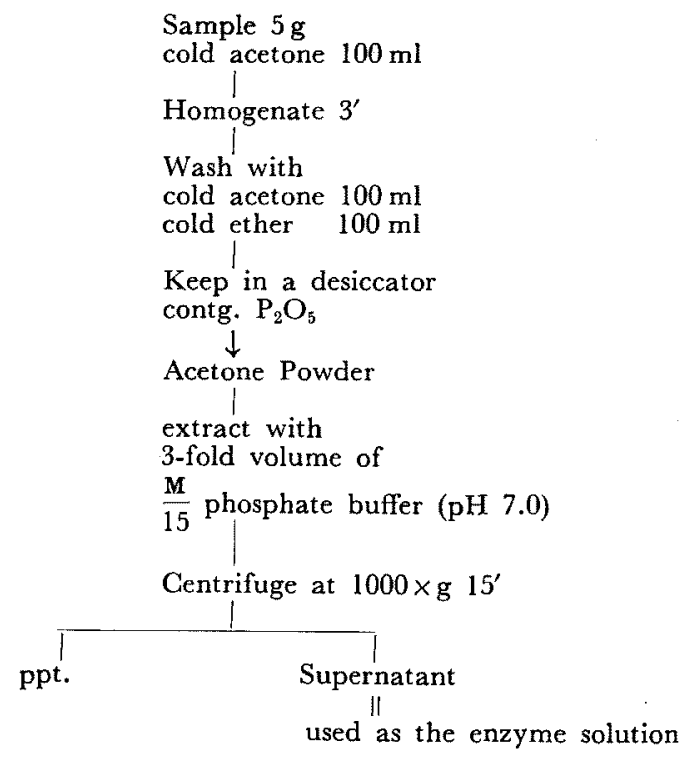

plant tissues were, therefore, homogenized with cold acetone at $-20 \sim-30^{\circ} \mathrm{C}$ and dried into powder. Such treatments proved very useful, in order to get rid of various contaminating compounds soluble in organic

9) I. Uritani and M. Miyano, Nature, 175, 812 (1955), 
solvents. The procedures of the acetone powder preparation and the extraction of enzyme are summarized in Tab. I. The reaction mixture contained $1.5 \mathrm{ml}$ of enzyme solution, $1.5 \mathrm{ml}$ of $5 \%$ casein and $1.5 \mathrm{ml}$ of buffer of $\mathrm{pH}$ 7.0. The test solution was incubated for 2 hrs. at $35^{\circ} \mathrm{C}$. After incubation, $1.5 \mathrm{ml}$ of $30 \%$ TCA was added.

Activity determination was carried out both colorimetrically and spectrophotometrically, as described above. In order to calculate the activity per mg. of protein-N, the amount of nitrogen in the enzyme solution was determined on double specimens by the semimicro Kjeldahl method.

\section{RESULTS}

Optimum $\mathbf{p H}$ The effect of $\mathrm{pH}$ upon the rate of hydrolysis of casein by the crude enzyme preparation is represented in Fig. 1.

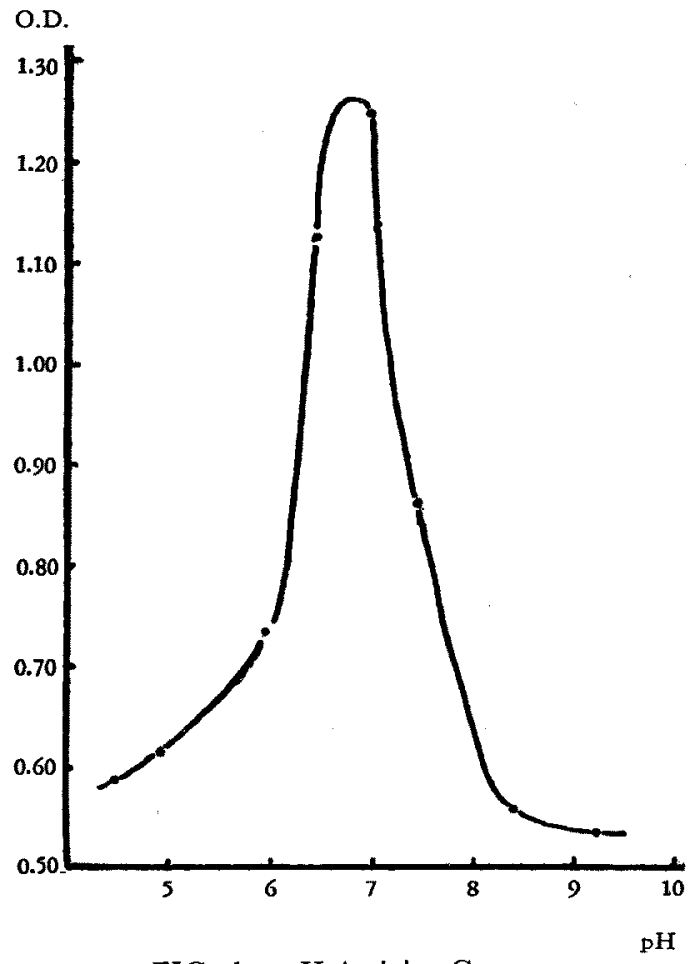

FIG. 1. pH-Activity Curve.

This rate seems to be maximal near the neautral point in phosphate buffer.

Optimum Temperature A maximal proteolytic activity can be observed near $35^{\circ} \mathrm{C}$. (Fig. 2).

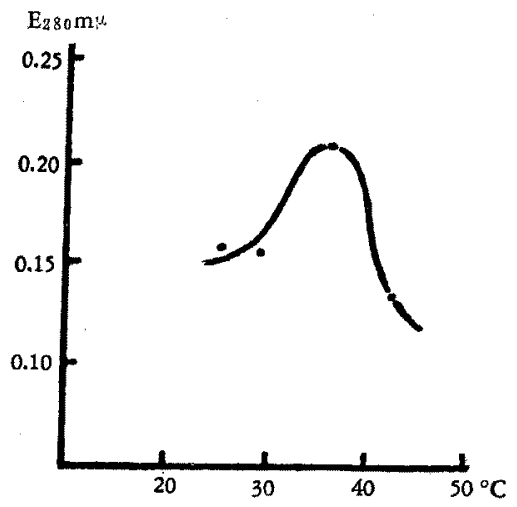

FIG. 2. Temperature Activity Curve.

Effect of Activators and Inhibitors The effect of several activators and inhibitors tested by measuring the degree of digestion, with and without the activators or inhibitors. In view of the experimental results shown in Table II

TABLE II

EFFECT OF ACTIVATORS AND INHIBITORS ON Proteolytic ACtivity

Expt. 1

$\begin{array}{cc}\text { Fraction } & \mathrm{E}_{280} \mathrm{~m} \mu \\ \text { Crude extr. } & 0.018 \\ 0.6 \text { sat. fract. } & 0.091 \\ \text { " + Cyst-SH } & 0.063 \\ \text { "+EDTA } & 0.066 \\ \text { "+ }+ \text { KCN } & 0.053 \\ \text { "+ PCMB } & 0.096\end{array}$

Final conc. of agents :

* Boiled Extract.

\section{Expt. 2}

$\begin{array}{cc}\text { Fraction } & \mathrm{E}_{280 \mathrm{~m} \mu} \\ 0.6 \text { sat. fr. } & 0.090 \\ \text { "+B. extr.* } & 0.138 \\ "+\mathrm{Fe}^{+3} & 0.134 \\ "+\mathrm{Fe}+2 & 0.080 \\ "+\mathrm{Mg}^{+2} & 0.088 \\ "+\mathrm{Mn}^{+2} & 0.092 \\ "+\mathrm{Cu}^{+2} & 0.082 \\ "+\mathrm{Zn}+2 & 0.086 \\ \text { "+Citrate } & 0.050\end{array}$

\section{$0.002 \mathrm{M}$ in Expt. 1.}

$0.0002 \mathrm{M}$ in Expt. 2.

relating that the addition of chelating agents such as ethylenediaminetetraacetate, citrate and potassium cyanide resulted in thirty to forty per cent inhibition, and that $p$-chloromercuribenzoate which is a $\mathrm{SH}$ inhibitor was as ineffective as cysteine, which is commonly known as a SH activating agent, it can be considered that the sulfhydryl group may not be responsible for the emergence of proteolytic activity while some kinds of cations are very probable to be effectively involved. Among all the metallic cations 
tested, ferric ion was found to cause a $50 \%$ acceleration of hydrolysis at a concentration of $0.0002 \mathrm{~m}$. This effectiveness of ferric ion was also ascertained by the Folin method.

The Proteolytic Activity of Black Rot Sweet Potato An individual of sweet potato root was separated into two parts. One half was kept at $25^{\circ} \mathrm{C}$. in the raw state (raw). The other half was sliced ( $2 \mathrm{~cm}$-thick), each of the slices being cut further into two portions of which the one was infected with Ceratostomella fimbriata (c.f.) and the other held without infection at $25^{\circ} \mathrm{C}$. (control). The control specimen was eatablished to examine the effect of slicing. Representative data of a series of experiments are shown in Fig. 3.

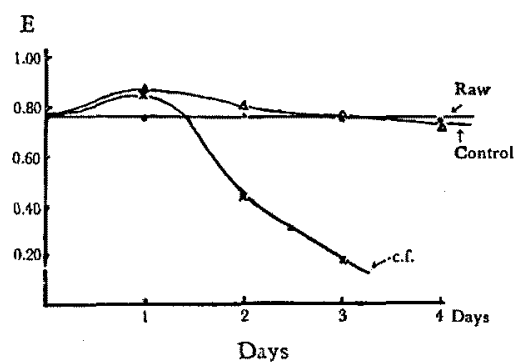

FIG. 3. Change of Proteolytic Activity in Black Rot Sweet Potato.

Activity measured by the Folin method was expressed as O.D. per $\mathrm{mg}$ proteine $\mathrm{N}$.

From this it can be seen that the proteolytic activity of black rot sweet potato declines appreciably at the $48 \mathrm{th} \mathrm{hr}$. while in case of both healthy and control specimens, activity remains almost at the same level even after 72 hrs. Such a diminution in proteolytic activity of the diseased tissues was also observed when another variety of sweet potato (Norin No. 10 var.) was tested

\section{DISCUSSION}

From the beginning it has been expected that proteolytic enzymes must exist in an active state in black rot sweet potato, since protein synthesis and protein reorganization observed in the metabolically activated tissues will require the activation of a sequence of processes which may supply amino acids and other lower molecular compounds for building bricks and which also must be smoothly pushed forth by the participation of proteolytic enzymes. The results obtained are, however, not in conformity with what we have expected. A more working explanation will be possible, i.e., that the activation of the protein synthesizing system will be evoked on the one hand, while on the other hand activity of the breakdown system gradually becomes retarded, protein synthesis thus being accelerated in a duplicate sense.

It is, however, dangerous to directly assume that the decrease in proteolytic activity signifies something resembling decrease in the turnover rate of protein metabolism. The protoplasm in the sound tissue adjacent to the infected will be activated by the stimulus of fungus penetration, and the proteolytic enzymes may be situated in the active cells in a state that makes them possible to act on the substrates more freely. In the discussion of the turn-over rate, therefore, the state of protoplasm, besides the activity of the enzymes, must be taken into consideration. Nothing should be mentioned on these points until further studies, for instance, the application of isotope techniques supply us more direct evidences. Be that as it may, the fact that the falling- off of proteolytic activity in black rot sweet potato has been demonstrated in vitro, must possess biochemical significance in consideration of the mechanism of the host-parasite interaction, in higher plants. 